\title{
THE POSSIBILITY OF REACHING THE FULFILLMENT OF MAASTRICHT CONVERGENCE CRITERIA IN SERBIA
}

\begin{abstract}
This paper analyzes the fiscal position of the Republic of Serbia as well as the ratio between its indicators and reference values anticipated by the Maastricht convergence criteria. According to the mentioned criteria, the public debt must not exceed $60 \%$ of the GDP, whereas the budgetary deficit must not exceed 3\% of the GDP, even though the majority of countries have set up stricter criteria in order to provide greater economic stability. The Republic of Serbia strives not to only fulfill the criteria set for the public debt be kept under $60 \%$ of GDP, but to decrease it to $45 \%$ of GDP. Taking into consideration the fiscal aggregates before and after the application of the fiscal measures in the following three year period it is shown that the measures should be applied further than this timeframe in order to fulfill the criteria needed to join the European Union. Based on the predictions shown in this paper it is clear that the Republic of Serbia will not be able to fulfill these criteria if it does not conduct a restrictive fiscal policy, which is inclusive in responding to the question of a structural deficit, a tax reform and an overall reform of the public sector, which is a good way to achieve the results predicted by the Maastricht convergence criteria, although not in the timeframe set by the Government of the Republic of Serbia.
\end{abstract} lic debt

Key words: budgetary deficit, fiscal strategy, Maastricht fiscal criteria, pub-

\section{Introduction}

The crisis of the public debt, as a typical manifest of the current global financial crisis, has struck numerous countries of the European Union which macroeconomic indicators are far above the prescribed borders of the Maastricht criteria. With an aim to control fiscal movements and overcome the recession

Assistant Professor Ana Jovancai Stakić, PhD, Megatrend University, Belgrade, e-mail: ajovancai@megatrend.edu.rs

** Jovana Stokanović, Teaching Associate, Megatrend University, Belgrade, e-mail: jstokanovic@megatrend.edu.rs

Vol. 12, No 2, 2015: 111-122 
period, numerous countries have introduced additional, even stricter rules. Extraordinary savings measures are in force and they should ensure sustainability in the management of the European economies. The level of the public debt prescribed by the Maastricht convergence criteria is $60 \%$ of the GDP; once the debt has exceeded the limit, legally binding rules for the reduction of the public debt come in effect, and there are sanctions for those countries that do not obey them. Certain countries have even determined the successive borders for their respective public debts, at a level lower than the Maastricht one is, due to the expected growth of the public debt in the time of the economic crisis.

As a state in which economy depends on the economic flows in the European Union to a great extent, Serbia is undergoing the identical pattern of the deterioration of the fiscal parameters. In times when the European Union is recording the further downfall of GDP and in comparison to other leading markets flows deeper into recession, the Republic of Serbia still has the aim to join the European Union and fulfill its economic requirements in order to obtain its membership. Even though the European economy remains in the unfavorable economic state, and its economic indicators have never been poorer, the Republic of Serbia still has a hard time reaching the economic standards proposed by the EU. In addition, if the Republic of Serbia manages to obtain the membership, there is a high possibility that since it is not economically ready for such a step, the further crises could occur, which was the case with the neighboring country, the Republic of Croatia.

\section{Maastricht convergence criteria}

The establishment and functioning of the European Monetary Union has been one of the most complicated segments in the process of the deepening of European integrations. What has made this process so much a complex one has been the readiness on the part of the European Union's countries to establish an economic and monetary union as well as a big difference in the then economic and social development of the member-countries. At that moment, after the successful forming of the internal market, the next step - in the form of the establishment of the European Monetary Union - was expected. In order to conduct a successful monetary integration, it was necessary to reduce the differences into tolerable frameworks through the measures of the economic policy, and, at the same time, to ensure approximately the same starting position towards a higher phase of integration. According to the Maastricht agreement, the European economic and monetary union member countries were supposed to satisfy the following criteria according to the monetary and fiscal policies until the year 1997 or 1998: 
Price stability, i.e. a sustainably low growth of prices and an average inflation rate not exceeding 1.5 percentage points above the average inflation of the three most successful member countries. Actually, inflation is measured on the basis of the comparative consumer price index - CPI.

1) Long-term interest rate - the average nominal long-term interest rate must not exceed $2 \%$ above the average of the three most successful member countries. The guideline for the determination of the interest rate is interest rates on long-term government bonds or comparative securities;

2) The amount of the budgetary deficit is determined in such a manner that the rate of the planned or achieved budgetary deficit does not exceed 3\% of the gross social product;

3) The public debt criterion anticipates that the amount of the public debt does not exceed an amount of $60 \%$ of the gross social product;

4) The stability of the foreign-exchange rate and the participation in the Exchange Rate Mechanisms II (ERM II). This criterion relates to respecting the stipulated margins of the foreign-exchange rate fluctuation, which were $\pm 2.25 \%$, without any more significant deviations in the time period of at least two years prior to the introduction of the common European currency. It is important that we point out at this point that - in the stated time period, when its currency is included in the Exchange Rate Mechanism - a potential member country has no possibility of self-initiatively devaluating its own currency against a currency of another EU member country with an aim of improving the competitiveness of its economy. The obligation of fulfilling the convergence criteria related to all the potential member countries of the Euro zone. These countries were expected to comply with the standards of budget-conscious living so as to create stable economic conditions for the introduction of the European currency. Amongst these conditions, the budgetary deficit was determined to have a share in the Gross Domestic Product not exceeding 3\%. If we take into consideration the fact that not one country fulfilled this concrete criterion in the year 1993, and that some countries had a deficit three and even four times as high (Greece, 15.4\%; Sweden, 14.5\%; Italy, $10.1 \%$ ), as well as the fact that each of these countries successfully satisfied the criterion until the year 1997, then a big success of the restrictive budgetary policy and the maintenance of budgetary discipline is evident. ${ }^{1}$ After "soft budgeting" which lasted for a number of years, it was necessary that modifications in the manner of conducting the fiscal and budgetary policy should be made if we wanted to create conditions for the introduction of a uniform currency. This is what the mem-

Jovanović, Gavrilović, (2001): Međunarodno poslovno finansiranje, Ekonomski fakultet, Beograd

Vol. 12, No 2, 2015: 111-122 
ber countries noticed, too, and the Maastricht agreement established the fiscal convergence criteria with a clear goal to, inter alia, use tight budgetary discipline to enable the original introduction and, after that, keeping the common Euro currency stable, too.

The European Union decided to opt for the application of a stabilization budget which was greeted with approval after the many years of the deficient financing of the budget within the European Union. Although, according to the opinions expressed by many people, the fiscal convergence criteria were set at a demanding level, they did represent a strong foundation of a uniform restrictive budgetary policy. The European Union understood that it was necessary that the budgetary consumption should be reduced to reasonable frameworks if they wanted price stability and the national currency stability, and they adapted their macroeconomic policy to achieving the goal. Although the fulfillment of the Maastricht criteria does not represent a condition for full membership in the European Union, for many new member countries, it represents the next strategic goal.

\section{Fiscal movements in Serbia in the period between 2000 and 2014}

After the political changes in Serbia in late 2000, there was an increase in the GDP which lasted until the second half of the year 2008, when, due to the financial and economic crisis, it recorded a fall. The current financial and economic crisis will undoubtedly change the manner of economic behavior at the both, micro- and macro levels. The up to date effects of the crisis and the forthcoming long-term challenges on the global level confirm the fact that it is not just an ephemeral phenomenon. ${ }^{2}$ Due to the degradation of the situation on the world financial markets, there has been a significant decrease in the flow of foreign capital, the domestic currency has depreciated and there have been inflationary blows, only to have been followed by a decline in aggregate demand, and, simultaneously, consumption as well, which has first led to slowing down, then to a fall in economic activities.

At the end of 2000 total public debt of the Republic of Serbia was $201.2 \%$ of its GDP. In the period from 2000 to 2008, there was a significant fall in the absolute level of the public debt as well as its share in the budgetary deficit. Thanks to the writing-off of a portion of the debt to the Paris and London Creditors Clubs, the external debt of the public sector of Serbia was reduced to the level of $28.3 \%$ in 2008. However, starting in 2008, the Republic of Serbia began to intensively increase its debt abroad, primarily to finance its

Stakic Nikola (2010): Proces sekjuritizacije kao faktor kreiranja globalne finansijske krize, Megatrend revija, vol 7. 
state budget's growing deficit, which no longer could have been financed by the privatization-generated incomes.

In the period between 2008 and 2011, the state became indebted by 6 billion Euros in total. At the end of the year 2011, the public debt was 12.3 billion Euros, in which amount - due to the different methodology between the Ministry of Finance and the IMF- only direct liabilities of the state at the central level of authorities were included (Table 1). Taking into consideration the indirect liabilities as well, both those related to the internal and the external debts, the total amount of the public debt was 14.46 billion Euros. Only in the year 2011 did the public debt increase by almost 2.5 billion Euros. The last indebtedness in the year of 2011 was in the month of September, when the state sold bonds worth one billion dollars on the international market. The very dynamics of the increased indebting has been increasingly more alarming as the fact came out that the larger portion of the amount has not been directed towards investments, capital projects and new employments, but rather primarily towards consumption and for covering the budgetary deficit.

Table 1: Public debt (in million Euros) ${ }^{3}$

\begin{tabular}{|c|c|c|c|c|c|c|c|c|c|c|}
\hline & 2005 & 2006 & 2007 & 2008 & 2009 & 2010 & 2011 & 2012 & 2013 & 2014 \\
\hline $\begin{array}{c}\text { Public debt - } \\
\text { total }\end{array}$ & $4,255.5$ & $3,837.0$ & $3,413.3$ & $3,161.6$ & $4,050.2$ & $4,571.8$ & $5,440.6$ & $6,495.6$ & $7,054.6$ & $8,225.2$ \\
\hline External & $5,364.1$ & $4,745.5$ & $4,615.8$ & $4,691.2$ & $4,408.6$ & $5,872.7$ & $7,238.6$ & $8,621.0$ & $10,244.9$ & $11,991.5$ \\
\hline Internal & $9,619.6$ & $8,582.6$ & $8,029.1$ & $7,852.7$ & $8,458.8$ & $10,444.5$ & $12,679.2$ & $15,116.7$ & $17,299.5$ & $20,216.7$ \\
\hline
\end{tabular}

In the first two years of the crisis, the Serbian fiscal deficit was even slightly lower than the one in the EU. However, starting in 2010-2011, the majority of the EU member countries abruptly declined their respective deficits, mainly through increasing taxes, whereas the Serbian deficit remained at an almost unchanged level of the year 2009, ranging between $4.5 \%$ and $5 \%$ of the GDP. The problem of the fiscal deficit in the year 2012 and the forthcoming years is in the range of alarming proportions which, due to bad macroeconomic indicators, can make it impossible for the country to service its own obligations and the public debt crisis.

Fiscal consolidation started in 2012 mostly by measures affecting incomes, by the increase and alteration of tax rates, and in lesser extent by the limiting growth of wages in public sector and pensions. In 2013 the goods export was increased by $25.8 \%$ and the import by $5.1 \%$. The current account deficit was reduced by the two-fifths, which, in addition to the increase in exports, contributed to fiscal consolidation. Increased taxes on corporate income (from $10 \%$ to $15 \%$ ) have positive effects. In the first 10 months of 2014 , the nominal

Ministry of Finance of the Republic of Serbia (2015): Public Finance Bulleting, Belgrade Vol. 12, No 2, 2015: 111-122 
and real growth of $33 \%$ and $30.3 \%$ respectively were recorded, compared to the same period in 2013.

In 2014, the economy fell into recession for the third time in six years, partially due to the devastating floods in May, 2014. Combining falling domestic demand, good agricultural outcome in 2013 and 2014, and low growth of regulated prices in 2014 caused the inflation to be pushed below target. Public debt has risen promptly and is estimated to have reached about $70 \%$ of GDP in 2014, while the fiscal deficit in 2014 was close to $7.5 \%$ of GDP.

\section{Current fiscal movements}

Public debt in February 2015 reached 23.7 billion Euros, or 71.9\% of GDP. The exports of goods in January 2015 were 777.3 million Euros, while the imports were 1,046.2 million Euros, which was an increase of $6.1 \%$ and $3.9 \%$, respectively. Overall the deficit was 268.9 million Euros, 5.9 million Euros less $(-2.1 \%)$ than in January 2014. Export-import ratio stood at $74.3 \%(1.6 \%$ higher than in January 2014). The current account of the deficit was reduced by 119 million Euros compared to December 2013, primarily due to a decrease in the foreign trade deficit of goods and services. Despite the negative effects of flooding during 2014, the current balance of payments (6.0\% of GDP) decreased slightly compared to 2013. It is expected to continue to improve in 2015, primarily due to the effects of fiscal consolidation. Total external debt in end-December 2014 reached 26029.9 million Euros, and compared with the end of the previous year it has increased by 284 million Euros.

Consolidated deficit in February 2015 is 11.3 billion dinars. In the structure of consolidated revenue the indirect taxes make up to $41.8 \%$, while the expenses for the salaries and pensions have the largest share in the expenditure side, $56.7 \%$. In the structure of consolidated revenue, the budget of the Republic of Serbia takes $58.2 \%$, while the expenditure side takes $39.8 \%$. There has been a downward trend in the primary deficit since the second quarter of 2012, as well as the increasing impact of the interest expense in the fiscal balance over the entire period.

The traditional measures of the sustainability of the public debt encompass the share of the balance and repayment of the public debt in the GDP, exports and budgetary incomes. Because of the balance of the public debt for the duration of the second quarter, all the measures of its sustainability have deteriorated. (Table2). In addition to the high-levels of the public debt, the rapid growth of the public debt in the last five years is even more worrying. The public debt is not sustainable if it grows faster than the capacity of the state to pay it off, to consider debt sustainable, it is necessary that its share in GDP is stable or declining, at a sufficiently low level. 
The possibility of reaching the fulfillment of Maastricht convergence criteria... 117

Table 2: The overview of the measures of the sustainability of the public debt ${ }^{4}$ (in percentage)

\begin{tabular}{|l|c|c|c|c|}
\hline & 2011 & 2012 & 2013 & 2014 \\
\hline Public debt/GDP & 48.2 & 60.2 & 63.8 & 65,1 \\
\hline Public debt/Goods \& services export & 128.9 & 149.8 & 140.1 & 138.0 \\
\hline $\begin{array}{l}\text { Public debt/Export of goods and services, } \\
\text { and remittances }\end{array}$ & 103.6 & 121.7 & 115.9 & 115.3 \\
\hline Public debt/ Budgetary incomes & 115.7 & 142.4 & 155.2 & 158.7 \\
\hline Public debt repayment/ GDP & 10.9 & 11.6 & 14.3 & 15.7 \\
\hline $\begin{array}{l}\text { Public debt repayment/Export of goods and services, } \\
\text { and remittances }\end{array}$ & 23.9 & 23.6 & 26.4 & 28.4 \\
\hline Public debt repayment/Revenue & 26.7 & 27.6 & 35.3 & 39.1 \\
\hline
\end{tabular}

\section{Fiscal consolidation and 2015-2017 fiscal strategy}

The first significant package of the fiscal consolidation measures were adopted at the end of 2012. Measures were related mainly to the revenue side, considering the increase of the large number of tax rates. The budget of the Republic of Serbia in 2014 continued the restrictive fiscal policy. The increase in the value added tax from $8 \%$ to $10 \%$ was expected to affect the revenue side, and there were positive expectations regarding the fight against the gray economy. The target deficit is very high because the increase of expenses is caused by the growth in interest rates, and the problem solving of the public and financial sector requires additional expenses.

During 2014, due to the implementation of the parliamentary elections and the consequences of the catastrophic flooding in May, the expenditures were further increased, and were additional funds to finance the troubled parts of the public sector were allocated. The fiscal consolidation measures have not yielded the expected result from certain tax categories. This is primarily related to VAT and excise tax on tobacco products as long as VAT revenues are lower than expected on several grounds. On the one hand there is still a low purchasing power of the population, inherited from the past, which is reflected in household consumption, while on the other hand, due to the flooding that occurred in May, there was a reduction in domestic production, which also affects the decrease in demand. Also, there was a change in consumption patterns since the demand for domestic products was substituted with demand for the imported goods, which further reflected on the collection of VAT on the imported goods, which in the first ten months of the current year

Ministry of Finance of the Republic of Serbia and the National Bank of Serbia

Vol. 12, No 2, 2015: 111-122 
compared to last year achieved the nominal and real growth of $10.4 \%$ and $8.1 \%$, respectively, while the reduced domestic production affected the lower recoveries of gross and net domestic VAT.

The medium-term fiscal frameworks with the proposed measures of fiscal consolidation provide a significant reduction in the general government deficit up to $3.8 \%$ of GDP by 2017 , and stabilize the public debt levels and reversing its trend (78.7\% of GDP in 2017). This implies a cumulative adjustment in the deficit of $4 \%$ of GDP. The targeted deficit in 2017 is $3.8 \%$ of GDP. After a strong reduction of the deficit in 2015 of around 2\% of GDP, in the following two years the adjustments will be somewhat lower. It should be noted that the application of specific measures leads to an increase in certain expenses, which reduces the effects of the adjustment. The projections of the fiscal aggregates in the period of 2015 - 2017 are based on the projections of macroeconomic indicators for the specified period, planned tax policy that implies further harmonization of the laws and the directives of the EU and the appropriate measures on the revenue and expenditure side, including the reform of large public companies.

Table 3: The fiscal aggregates in the period of 2014-2017, in\% of GDP, the scenario without the use of fiscal consolidation ${ }^{5}$

\begin{tabular}{|l|c|c|c|c|}
\hline & Estimation & \multicolumn{3}{|c|}{ Projection } \\
\hline Year & 2014 & 2015 & 2016 & 2017 \\
\hline Public revenues & 40.9 & 40.3 & 39.5 & 39.1 \\
\hline Public expenditures & 49.0 & 47.6 & 46.3 & 45,9 \\
\hline The consolidated fiscal result & -8.1 & -7.3 & -6.8 & -6.8 \\
\hline The debt of the government sector & 69.9 & 78.7 & 83.1 & 86.1 \\
\hline Real GDP growth & $-2.0 \%$ & $1.0 \%$ & $1.3 \%$ & $1.8 \%$ \\
\hline
\end{tabular}

Fiscal consolidation measures in the period from 2015 to 2017:

1) The reduction of salaries of the public sector employees- the saving on this basis at the level of the general government should be about $0.5 \%$ of GDP annually;

2) Reducing pensions- it is estimated that the impact of these measures on the deficit reduction is to be around $0.5 \%$ of GDP;

3) New rule for the indexation of wages and pensions- the effects of these measures are not significant in the first two years (0.1 - $0.2 \%$ of GDP), but the effect in 2017 will be around $0.5 \%$ of GDP as significantly higher indexation predicts.

4) The rationalization of the public sector- reducing the number of employees by $5 \%$ annually in the next three years should bring savings

Ministry of Finance of the Republic of Serbia 
of around $0.3 \%$ of GDP annually. It is calculated that the largest part of this reduction will be achieved by natural turnover of staff, by retiring, with limited filling of the vacancies.

5) Reducing subventions- in 2015, the effects on the reduction of the deficit should be around $0.2 \%$ of GDP, while in 2016 this effect should increase to around $0.5 \%$ of GDP.

6) The savings on goods and services- savings of at least $0.1 \%$ of GDP;

7) The reform of the public enterprises- the fiscal effects of the restructuring of the public enterprises will be reflected in the profit payment or the budget financing via dividends. On this basis an increase is expected to go between $0.3 \%$ and $0.5 \%$ of GDP annually.

8) The fee for gas transport- $0.2 \%$ or $0.3 \%$ of GDP annually;

9) The financing of local self-government- should reduce the general government deficit to around $0.2 \%$ of GDP.

Table 4: Basic fiscal aggregates in the period 2014-2017 in\% of GDP, scenario with the implementation of fiscal consolidation measures ${ }^{6}$

\begin{tabular}{|l|c|c|c|c|}
\hline \multicolumn{1}{|c|}{ Year } & 2014 & 2015 & 2016 & 2017 \\
\hline Public revenues & 40.9 & 40.3 & 39.1 & 38.2 \\
\hline Public expenditures & 48.9 & 46.1 & 43.8 & 41.9 \\
\hline The consolidated fiscal result & -7.9 & -5.9 & -4.7 & -3.8 \\
\hline The debt of the government sector & 69.9 & 77.7 & 79.2 & 78.7 \\
\hline Real GDP growth & $-2.0 \%$ & $-0.5 \%$ & $1.5 \%$ & $2.0 \%$ \\
\hline
\end{tabular}

Fiscal Policy after 2017 must be focused on further deceleration by decreasing the relative share of the deficit in GDP and the fiscal adjustment on the expenditure side.

The public debt of the Republic of Serbia is divided into direct and indirect obligations or commitments on behalf of the Republic and liabilities arising from guarantees, which are issued by the Republic, and in favor of other entities. Direct and indirect liabilities are further divided into domestic debt and external debt, depending on whether the obligations incurred by borrowing on domestic or foreign markets. One of the major economic and political goals of the Republic of Serbia is joining the EU therefore the most important thing is to adjust domestic methodology in accordance with the European standards. The public debt is analyzed regularly and on the basis of the criteria laid down in the Maastricht Treaty, which represents systematized guidelines to ensure the sustainability of the public debt, the fiscal system and the macroeconomic stability. According to these criteria, in the public debt it should be included, in addition to the direct obligation of the central

Ministry of Finance of the Republic of Serbia

$$
\text { Vol. 12, No 2, 2015: 111-122 }
$$


government, and non- guaranteed debt of local authorities, but the debt based on direct and indirect liabilities on which the Republic does not make payments, should be excluded.

Table 5: The structure and the projection of the state of the public debt according to Maastricht criteria by 2017 (in billion dinars)

\begin{tabular}{|l|c|c|c|c|c|}
\hline & $\mathbf{2 0 1 3}$ & $\begin{array}{c}\mathbf{2 0 1 4} \\
\text { projection }\end{array}$ & $\begin{array}{c}\mathbf{2 0 1 5} \\
\text { projection }\end{array}$ & $\begin{array}{c}\mathbf{2 0 1 6} \\
\text { projection }\end{array}$ & $\begin{array}{c}\mathbf{2 0 1 7} \\
\text { projection }\end{array}$ \\
\hline Total direct obligations & 1912.4 & 2307.6 & 2511.0 & 2712.0 & 2893.5 \\
\hline guaranteed debt & 209.0 & 198.6 & 233.8 & 226.5 & 192.4 \\
\hline Other government sector debt & 5.6 & 2.2 & 1.3 & 0.7 & 0.4 \\
\hline Debt of local authorities & 81.3 & 84.3 & 95.3 & 102.4 & 109.7 \\
\hline Debt of social security institutions & 0 & 0 & 0 & 0 & 0 \\
\hline Public debt of the Republic of Serbia & 2208.3 & 2592.7 & 2841.4 & 3041.6 & 3196.0 \\
\hline $\begin{array}{l}\text { Public debt of the Republic of } \\
\text { Serbia/GDP }\end{array}$ & $57.0 \%$ & $66.8 \%$ & $71.6 \%$ & $72.5 \%$ & $71.7 \%$ \\
\hline
\end{tabular}

\section{Conclusion}

Given the most important strategic goal set by the Republic of Serbia - its membership in the European Union - and apart from the numerous structural and administrative adaptations, it is important that the ratio between the basic economic indicators and the values anticipated by the Maastricht criteria should be kept in check. Although the fulfillment of the convergence criteria is not a condition for being granted a membership in the Union, it certainly represents a goal towards the accomplishment based on which we should direct the conducting of the economic policy. The analysis of the so-far fiscal movements in Serbia as well as the projections of those movements present a clear picture of which extent we are far away from the fulfillment of the Maastricht criteria. However, the improvement of all the aforementioned fiscal elements must primarily have as a goal the improvement of the efficiency of the domestic economy, the reduction in unemployment as well as the stability of the domestic currency. What is important is to change the course of the overall economic policy and especially the fiscal policy. To avoid the crisis of the public debt, which realistically threatens, it is necessary that the public finance should be consolidated. The additional problem is the one represented by the weak efficiency of the economy which should be improved in terms of generating a wider scope of the GDP and exports. Just as it is the case with

Fiscal Council of the Republic of Serbia 
a number of countries within the European Union when the creation of a monetary policy is concerned, Serbia must obey a thrifty life style and use a restrictive fiscal policy to try to restore the weary economy. Big public consumption and its unfavorable structure are the consequences of conducting an inadequate economic policy based on the inflow of foreign capital according to the privatization activities and speculative possibilities. When, due to the effectualization of the economic crisis, such a policy has proved to be impossible to sustain, it has become clear that Serbia's approach in conducting a fiscal policy, which is inclusive in responding to the question of a structural deficit, a tax reform and an overall reform of the public sector is a good way to achieve the results predicted by the Maastricht convergence criteria.

\section{Literature}

- Fiscal Council of the Republic of Serbia http://www.google.rs/url?q=http://www. mfin.gov.rs/UserFiles/File/dokumenti/2015/Fi skalna\%2520strategija\%25202015- 2017(1). pdf\&sa=U\&ei=8plAVYjdINHiaKGfgdgG\&ved=0CBMQFjAA\&sig2=QqJZS _MRsF1Ttg6 A6qwWAg\&usg=AFQjCNHKMpi7Fkmklrt0caNgAnpvHwZpEw

- Fiscal Council of the Republic of Serbia http://fiskalnisavet.rs/images/fiskalna konsolidacija.pdf (04.2015.)

- Gnjatović, D., Jovancai, A., (2009): Stepen spoljne zaduženosti Srbije, Ekonomski fakultet, Kragujevac.

- Jovancai, A., (2011): „Realizacija Nacionalnog investicionog plana Republike Srbije u periodu 2006-2010“, Megatrend revija, vol 8 (1).

- Jovanović Gavrilović, P., (2001): Međunarodno poslovno finansiranje, Ekonomski fakultet, Beograd.

- Leeper, Eric, Todd B. Walker, and Shu-Chun S. Yang, (2009): Government Investment and Fiscal Stimulus in the Short and Long Run, National Bureau of Economic Research Working Paper No. 15153

- Ministry of Finance and Economy of the Republic of Serbia

- Nikolić, G., (2011): „Analiza stepena ispunjenosti mastrihtskih kriterijuma konvergencije:Srbija i zemlje regiona“, Finansije, Ministarstvo finansija Republike Srbije.

- Orbán, G. and G. Szapáry (2004): The Stability and Growth Pact from the Perspective of the New Member States,MNB Working Paper 4/2004

- Stakić, N., (2010): „Proces sekjuritizacije kao faktor kreiranja globalne finansijske krize“, Megatrend revija, vol 7 (1).

- Woodford, Michael, (2011): „Simple Analytics of the Government Expenditure Multiplier“, American Economic Journal: Macroeconomics, 3, 1-35. 